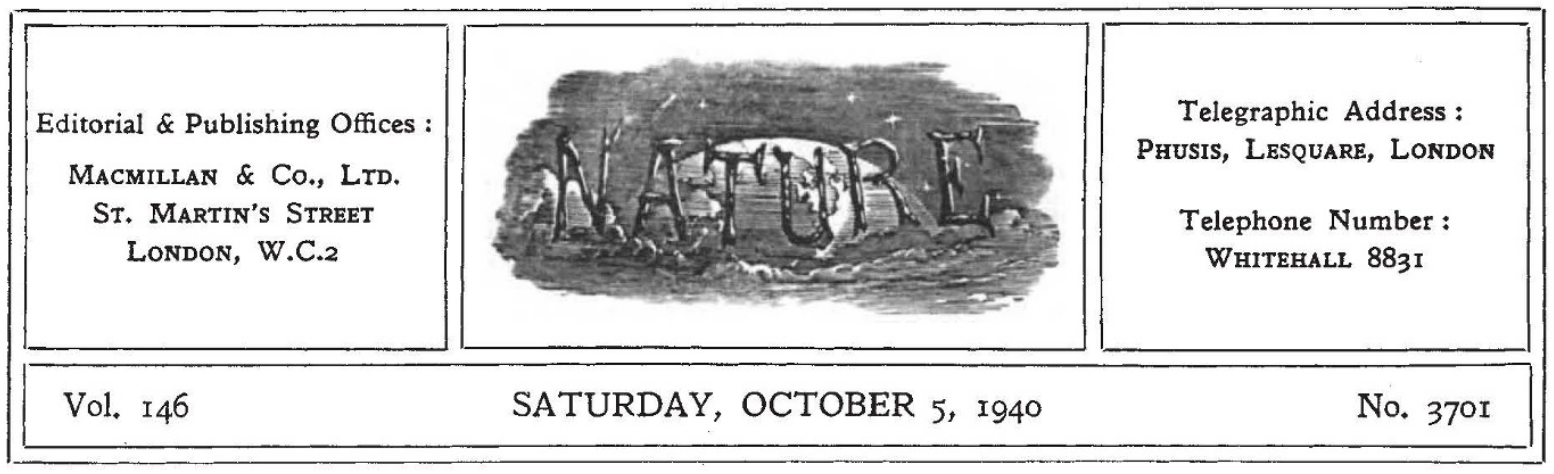

\title{
EVACUATION AND EDUCATIONAL POLICY
}

$\mathrm{T}$ HE well-balanced report to the Fabian Society which has been edited by Richard Padley and Margaret Cole under the title "Evacuation Survey" is the most comprehensive of a number of admirable reviews of the situation which have already appeared.* Besides the investigations carried out by the Department of Social Science of the University of Liverpool and the articles in the Quarterly Review and the Political Quarterly which have already been commented on in these columns, there are Lady S. D. Simon's "The Children in War-Time" issued by the Workers' Educational Association and a further study "Evacuation : Failure or Reform" by F. Le Gros Clark and R. W. Toms, also issued by the Fabian Society.

The main impression which Mr. Padley and Mrs. Margaret Cole's report leaves is the lack of vision and co-ordination in the original planning. The absence of these was the prime cause of the confusion and difficulties which went far to wreck the original scheme and did the greatest mischief to the educational system. Until that position has been rectified it is idle to expect the firm action which is still required to bring order again into the field of education and prevent the perpetuation of damage to health and educational services alike.

On this point the criticism of the Government is sharp and severe. Confusion of thought appears to have characterized the conception of the scheme as well as its execution. Circulars issued by the Ministry of Health instructing the local authorities how to deal with evacuation problems convey the impression of a Government using the decentralized local government system, not as a means of

* Evacuation Survey : a Report to the Fabian Society. Edited by Richard Padley and Margaret Cole. Pp. viii +296 . (London: George Routledge and Sons, Ltd., 1940.) 10s. 6d. net. making allowances for local needs and resources, but rather as a method of shirking its own responsibility. Difficulties are admitted with no long-term programme for their solution. Heavy burdens of organization are placed on small local authorities, ill-equipped for such detailed administration. Voluntary effort is continually relied on to provide services which the Government is unwilling to organize or finance.

Of the Departments concerned with administrating the scheme, the Board of Education, which alone showed sufficient imagination, was lacking in initiative, and allowed itself to be refused any major share of control. The Ministry of Home Security was obsessed with the prospect of destruction and too busy with other aspects of civil defence. The Ministry of Transport saw the whole thing purely as a technical problem; and the Ministry of Health, which was responsible for the scheme, was far too timid to develop any serious policy. Over them all was the control of a parsimonious Treasury, which correctly interpreted the Government's attitude in resisting the expenditure which would have been necessary to assist the local authorities in offering proper services for the evacuees.

The survey does not suggest that any of the steps which the Government neglected would, in the absence of the heavy bombing which was expected, have made a complete success of the scheme. The shrewd and severe criticism, however, makes it very plain that with efficient planning and proper co-operation between the many local authorities and services the scheme would have come much nearer to achieving success. The Ministries at the centre failed to supply the wise and energetic guidance that was essential, 
and it is well that we should remember that the considered judgment of the first evacuation scheme leads inescapably to the conclusion that the Civil Service, through lack of vision and constructive ability, missed an immense opportunity.

Sobering as are the reviews of the national scheme and the experiences of its working in different districts, or of the effects of the scheme on local administration or the various social services which are contributed to this volume, its main outlook and criticism are not retrospective or negative, but constructive. An opportunity was missed because, Mrs. Cole remarks, the scheme was unattractively drawn up "by minds that were military, male and middle class". They were not imaginatively alive to the real issues, human and social, underlying what was to them a mere matter of civil defence. The great value of this book is that it directs attention to the opportunities which are still before us and indicates some of the factors which require weighing and analysis.

The note of vision which characterizes the third part of the book in reviewing the outstanding problems of evacuation enables it to make a real contribution to those important aspects of education and juvenile and adolescent welfare which are with us as part of our war effort and as part of the social reconstruction which must proceed during, and not merely after, the War. The startling disparities between outlook and social habits and conditions which have been revealed to many for the first time by the evacuation have indeed to some extent loosened some of the former obstacles to reform. With a wide vision and a firm but sympathetic handling of these problems, much might yet be done to consolidate the solid gains in health which have in some districts already resulted, and to retrieve the mistakes which parsimony or sheer administrative incapacity have perpetrated. Success can only come when not merely the House of Commons but the whole country acquires a real interest in education and in the contribution to the national welfare which the school social services represent.

It is only possible to select a few of the possibilities for mention here. To take education in its narrowest sense in the first place, the outbreak of systematic bombing attacks with a main objective in the disintegration of civilian morale makes the provision of an education as complete as possible a matter of vital defence as well as a desirable end of statecraft.
It must be recognized that not all the dislocation of education has come from evacuation; but there can be no question that the time has come when full educational facilities must be restored. Even if the whole time is not spent in a school, full-time education can and must be provided both in the reception and in the evacuation areas. Moreover, it is remarkable that the importance of bringing immediately into operation the Education Act of 1936, which raises the school-leaving age to the end of the term in which the child becomes fifteen, is now being urged not only by education authorities but also. by other bodies of widely divergent interests.

The development and prosecution of an adequate education policy in this way involves naturally some reorganization and co-ordination. It will not be sufficient to hand over to the Board of Education all problems connected with the evacuation and billeting of children, including nursery school children, or to return immediately to the local education authorities all school buildings which are not absolutely indispensable for purposes connected with the War. Imagination and courage and real determination as well as administrative efficiency will be demanded of the Board of Education if it is to execute the required policy with success. No longer must the Board allow itself to be treated as a poor relation and overridden by other Departments.

The question of accommodation supplies an admirable instance in point. If the scheme at present operating is to succeed at all, it must have available not merely accommodation such as billeting premises but also adequate premises for teaching. A general survey of existing premises, which might well yield much of the accommodation required for all purposes, is urgent. Preliminary examination in some of the reception areas indicates that premises are certainly to hand which could frequently be used without drastic alteration. Wise and inspired improvisation could undoubtedly better the situation.

Besides this the question of new building construction must be faced. Here it must be remembered that new buildings are permanent and change the face of the villages and small towns. They must therefore be designed to meet the future needs of the people in the villages and towns as well as the immediate situations. School buildings in many rural areas are hopelessly out of date, apart from their inadequacy to meet the situation arising out of evacuation. The policy of 
building senior schools in the countryside needs reviving and implementing. Moreover, where premises are lacking or inadequate and no fresh school building has been constructed this situation could often be met by the construction of some type of hall or village centre, which could serve for teaching purposes during the War and afterwards be an asset to the neighbourhood.

The educational position arising out of evacuation abounds in such possibilities of harnessing immediate necessities to future needs and developing national assets rather than frittering away resources in improvisations. What is essential is far-sighted planning and bold leadership inspired by the conviction that a nation's youth is one of its greatest assets, and the wise training of the children and adolescents a sure safeguard of its morale. Only such a conviction will supply the drive essential to carry through the measures required to safeguard the health of the children whether in reception or evacuation areas, to ensure that the diet of the children of the nation is kept at a level affording at least adequate protection against the deficiency diseases, and sufficiently fortified by a good standard of nutrition to be resistant to epidemic infections, thus preserving us the invaluable asset of a healthy and welldeveloped young generation.

No less determination will be needed to repair the havoc already wrought in secondary and higher education. Here, as Helen Bentwich points out, apart from the acute difficulties imposed by the absence of suitable premises and equipment, billeting offered particular difficulties. In the absence of careful planning of billeting in relation to the actual educational facilities for secondary education in the reception areas, efficient teaching of these children proved almost impossible. Here the evacuation experience endorsed the importance of further regional co-operation in the direction suggested both in the Hadow Report and in a subsequent P E P broadsheet on the control of education.

This Evacuation Survey makes many other admirable suggestions. The chapter on psychological aspects is particularly valuable not only in respect of the warning it gives in regard to juvenile delinquency if we fail to handle wisely the question of small children and separation from their homes, but also in regard to camps and to the needs of parents or foster parents. Some teachers might well consider whether they could not relieve foster parents of some of their heavy responsibilities out of school hours. There are emotional as well as economic problems in evacuation, and the original scheme broke down mainly on the human and domestic side. The vagaries of human relationships were insufficiently considered. Unless the State shoulders its responsibilities in these matters the opportunities for constructive work which evacuation offers will be missed as will the opportunities before the National Youth Committee.

The question really before us is whether we care sufficiently for the welfare of youth to put into its training the thought and effort which are required to meet these new opportunities. A consciousness of the importance of youth as a national asset may provide the first stimulus. Equally our plans must provide for the throwing up of leaders, and for the means by which youth can play its part not only in the national effort now but also in the develop. ment of a new social order after theWar. This evacuation survey, for all its trenchant criticism of past mistakes or ineptitude, demonstrates emphatically the opportunities still confronting us in social reform in this field of education. If these opportunities are firmly seized, evacuation may yet leave the country a heritage of camp schools, village halls and clubs, nursery hostels and the like such as it has never before enjoyed. Permanent links might be established between urban and rural communities, and a sense of the values of right feeding, of air and sunshine, of child nurture and of social enterprise carried to half the homes of Britain.

To achieve this we need indeed central direction imaginatively alive to these human and social issues, and making wise and effective use of the administrative systems already available. Such direction is needed to ensure due co-ordination not only of the work of the different Government departments but also of such activities as those of the National Youth Committee and the numerous voluntary organizations concerned with the welfare of youth. We need, too, a large and wholesome display of local initiative, exploring and discovering its own solutions for difficulties as they are encountered. Supported by an increasingly enlightened public opinion we may see at last the actual beginning of compulsory day continuation schools until the age of eighteen, the elimination of some of the anomalies of local administration which have hindered the development of our educational system and the implementing of the constructive proposals of the Spens Report and of the provisions of the Fisher Act placed on the Statute Book at the end of the War of 1914-18. 